\title{
Interaction of Plastics with Marine Species
}

\author{
Rafet Cagri OZTURK ${ }^{1}$, Ilhan ALTINOK ${ }^{1, *}$ \\ ${ }^{1}$ Karadeniz Technical University, Department of Fisheries Technology Engineering, 61530, Trabzon, Turkey
}

\author{
Article History \\ Received 02 March 20120 \\ Accepted 21 April 2020 \\ First Online 22 April 2020

\section{Corresponding Author \\ Tel.: +904623778083} \\ E-mail: ialtinok@ktu.edu.tr
}

\section{Keywords}

Plastic pollution

Mesoplastics

Microplastics

Nanoplastics

Plastic ingestion

Metadata analysis

\begin{abstract}
The plastic litter in the seas and oceans has become one of the major threats for environment and a wide range of marine species worldwide. Microplastics are the most common litters in the marine environment corresponding to $60-80 \%$ of the total litter in the world's seas. The risk factor of plastics is inversely associated with the size of the plastic. In the present study, we reviewed the state of knowledge regarding the impact of plastic pollution on marine environment and marine species, assessing the ingestion incidences, elimination of plastics, interactions of plastics with other pollutants, and effects on photosynthesis. Records of marine species ingesting plastic have increased and begin to attract considerable attention. Metadata generated from the review of related papers in the present study was used to evaluate the current knowledge on the plastic ingestion by different marine species. The retrieved data from reviewed articles revealed that the ingestion of plastic by marine animals have been documented in more than 560 species including fish, crustaceans, mammals, sea turtles, bivalves, gastropods even in sea stars and limpets. The size of ingested plastics varied from species to species generally depending on the feeding behavior. Microplastics showed the highest number of bibliographic citations in the plastic ingestion studies. They are mostly ingested by planktivorous and filter feeder species. Meso, macro, and occasionally megaplastics are reported in marine mammals and sea turtles since they often confuse plastic for their prey. The sensitivity and size of the detected plastics may vary based on the analytical plastic detection methods.
\end{abstract}

\section{Introduction}

Plastic is one of the important materials obtained from the processing mixture of plastic polymers, additives, and filling materials. The plastic production at commercial scale was started in the 1940s with the industrial development. Since then plastic littering has been a growing problem in both aquatic and terrestrial environments (Wu, Nahil, Miskolczi, Huang, \& Williams, 2016). There are various types of plastics that include polyethylene terephthalate (PET), high-density polyethylene (HDPE), low-density polyethylene (LDPE), polyvinyl chloride (PVC), polyethylene (PE), polypropylene (PP), polytetrafluoroethylene (PTFE), and polystyrene (PS) (Allen, Kalivas, \& Rodriguez, 1999). Plastics are used in many sectors such as packaging, agriculture, construction and building materials, automotive, electrical and electronics, appliances, mechanical engineering, transportation, furniture, household leisure, and sports. Hence, they become a part of routine human life (PlasticsEurope, 2018). On the other hand, the total foreign trade volume of plastic raw materials in the world is around 500-600 billion dollars annually (PlasticsEurope, 2018), and there is no chance to reduce plastic production or use of plastics, at least for now. 
The world's plastic production is $\sim 359$ million tons/year and over $17 \%$ of them produced in Europe (PlasticsEurope, 2018). More than half of the plastics are produced for a single-use and up to $2.7 \%$ of them end up in the ocean (Li, Tse, \& Fok, 2016). Microscopic plastics can be originated from both primary and secondary sources. When large plastics such as nets, tires, line fibers, and plastic containers move from land to oceans, they break down from larger pieces to smaller pieces over time under various environmental conditions with aging processes to form secondary microplastics (da Costa, Santos, Duarte, \& Rocha-Santos, 2016). Some of the microplastics are primary microplastics manufactured as a microscopic size and directly released in the environment. Primary microplastics are also used in face washes, detergents, cosmetics, textiles, toothpastes, and medicines as a vector (Patel, Goyal, Bhadada, Bhatt, \& Amin, 2009; Zitko \& Hanlon, 1991). Approximately 19-31\% of microplastics in the oceans are originated from primary microplastics (World Economic Forum, 2016). Although microplastic was first defined as a piece of plastic $(5 \mathrm{~mm}$ or smaller), there is a confusion in the definition of the microplastics. Based on their size plastics can be classified as megaplastics (over $1 \mathrm{~m}$ ) macroplastics (1 m$2.5 \mathrm{~cm}$ ) mesoplastics $(2.5 \mathrm{~cm}-5 \mathrm{~mm})$ microplastics (5 $\mathrm{mm}-1 \mu \mathrm{m}$ ) and nanoplastics (less than $1 \mu \mathrm{m}$ ) (Chatterjee \& Sharma, 2019).

To draw attention to plastic pollution, one of the fastest growing sources of pollution, the main theme of the Science 20, the scientific leg of the G20 summit held in Japan in March 2019, was "global warming and plastic pollution in the oceans". All species are facing a serious environmental and health problem on a global scale due to plastic litters. Plastic litters can be transported from land to aquatic environment with the help of factors such as precipitation, wind and various surface runoff (Schwarz, Ligthart, Boukris, \& van Harmelen, 2019). Approximately $80 \%$ of the plastic waste in the oceans are coming from terrestrial land waste through rivers (Horton, Svendsen, Williams, Spurgeon, \& Lahive, 2017). Around 100-160 million tons of plastic waste are produced annually worldwide, and these amounts correspond to $8-12 \%$ of the total mass of urban solid waste (Veksha et al., 2017). Plastic litters coming from the Danube River to the Black Sea are about $7.5 \mathrm{mg} / \mathrm{m}^{3} / \mathrm{s}$ which is equivalent to 1553 tons of plastic in each year (Lechner et al., 2014). On the other hand, it has been estimated that by 2025, 250 million tons of plastics will be transferred to the oceans (Jambeck et al., 2015).

During the transportation of plastics from land to oceans, they are broken into smaller structures with various biological, physical, and chemical processes to form micro particles called microplastics (mPS) or nanoplastics (nPS) depending on their size (Eriksson \& Burton, 2003). Studies have shown that $60 \%$ to $80 \%$ of the litter in the seas and oceans are come from plastics and most of them are microplastics (Browne, Galloway, \& Thompson, 2007). Silc et al. (Šilc, Küzmič, Caković, \&
Stešević, 2018) collected 120 samples of water and sediment from the different stations in the southern Adriatic Sea, to investigate the presence of plastics. They found that $80.6 \%$ of the samples contain plastic and $38.7 \%$ of them consist of polystyrene plastics. In addition to many other uses, the polystyrene especially used in food service and packaging which can pass directly to the food chain (Y. Lu et al., 2016).

Current studies show that the risk factor from plastics increases inversely with the particle size (Fabio, 2019; Mattsson et al., 2015; Pitt, Kozal, et al., 2018). Therefore, research on plastic toxicity is now concentrated on nPS. Although there are no clear limits in the literature for naming small-sized plastic particles according to their size, plastic particles generally smaller than $100 \mathrm{~nm}$ are called nanoplastics. As is known, polymers are structures formed by combining polymer chains of various lengths. These chains come together as a result of the physical interaction of the hydrogen bonds with weak spaces or weak secondary bonds such as Van der Waals (Koelmans et al., 2015). These weak interactions are known to be sensitive to breaks even at low energy levels. This sensitivity allows nano-sized particles to rupture from the surfaces of plastics when exposed to external influences such as friction (Ferreira, Venâncio, Lopes, \& Oliveira, 2019). This situation is shown as the most important secondary source of nPS (Ferreira et al., 2019). On the other hand, thermal cutting / processing steps of products such as polystyrene (Zhang, Kuo, Gerecke, \& Wang, 2012) and 3D printers (Stephens, Azimi, El Orch, \& Ramos, 2013) are shown as major primary sources for nanoplastics. Unfortunately, it is very difficult to say something about the amount of nPS in the environment, which are constantly increasing, since a practical and field-usable technique has not yet been developed for nPS detection.

Plastic particles can be found in water column and sediment but the concentration of the plastic particles more than 100 times higher in sediment than that of water column. The amount of plastic particles in sediment is depending on the distance from the coastline, depth of the sediment, and flow rate. The density of the polymers determines where they locate in the water column. Based on their density, microplastics (mPS) polymers separate in water column. Polymers (polyethylene and polypropylene) that have lover density locate on the marine surface while heavy or dense polymers (acrylics and polyesters) can be found in deep sea (Erni-Cassola, Zadjelovic, Gibson, \& ChristieOleza, 2019).

\section{Literature Review}

Nowadays plastic pollution attracts considerable attention due to their ingesting by aquatic species have been increasing each day. However, global assessment of current status is scarce (Azevedo-Santos et al., 2019; Markic, Gaertner, Gaertner-Mazouni, \& Koelmans, 
2019; W. Wang, Ge, \& Yu, 2020). In this regard, we have conducted complete and comprehensive literature review to provide up to date information on plastic ingestion by marine species in the estuarine and marine environment worldwide, including fish, mammals, crustaceans, mollusks, sea turtles, excluding birds. We performed Web of Science (http://apps.webofknowledge.com) searches to retrieve papers on plastic ingestion of marine species using the following combinations of words;

i) "plastic" and "stomach" and "marine"

ii) "plastic" and "ingestion" and "marine"

iii) "marine debris" and "intake"

iv) "marine debris" and "ingestion"

The titles and abstracts of the retrieved publications were screened, and potentially relevant papers were examined individually. Furthermore, we have also evaluated plastic ingestion studies plotted in global distribution map at litterbase.awi.de website where almost 1200 scientific publications on interactions of species with marine litters are listed. The last search was performed on 15/February/2020. Ultimately, 334 papers reporting plastic ingestion by marine species, with the majority of the reviewed papers are published after 2012, are retained and systematically reviewed (Supplementary Table S1). From these studies, scientific name of species that ingested plastic, family that species belong, sampling location of the species, and size group of the plastic are recorded. Missing family information gathered from the FishBase (Froese and Pauly, 2018). Plastics were classified based on the classification described above. Chemical compositions of the plastics are not taken into consideration. Species sampled from local markets were tagged as "Sampled from market".

\section{Data Analysis}

The present study is a complete assessment of plastic ingestion by marine species in estuarine and marine environment. Species included in this study were classified as Fish, Mammals, Sea turtles, Crustaceans, Bivalve, and Others. Gastropods, sea stars, sea cucumbers, polychaetas, and tunicates were subsumed under "Others" since plastic ingestion incidences in these groups were limited. Species were categorized based on their family and sampling location. Annual published papers reporting plastic ingestion incidences in marine species are presented in Figure 1. Based on the reviewed articles, plastic ingestion in marine species has been documented in over 560 species; from 133 fish families belonging to 34 orders, 11 mammalian families belonging to 3 orders, 19 crustaceans families belonging to 3 orders, 2 sea turtle families from a single order, 11 bivalve families belonging to 10 orders and 17 different families from different classes including sea stars, sea cucumbers, tunicates and gastropods (Table S1).

Metadata generated following the literature review was graphically analyzed. To visualize research effort in estuarine and marine environments worldwide based on reviewed papers, representative coordinates for each plastic ingestion studies were used to generate a distribution map with $\mathrm{R}$ packages of ggplot2, maps, and rnaturalearth. Microplastic ingestion studies on specimens obtained from unknown origins and markets are excluded from the map metadata. Circos plot was generated using the circlize package (Gu, Gu, Eils, Schlesner, \& Brors, 2014) in R software to visualize

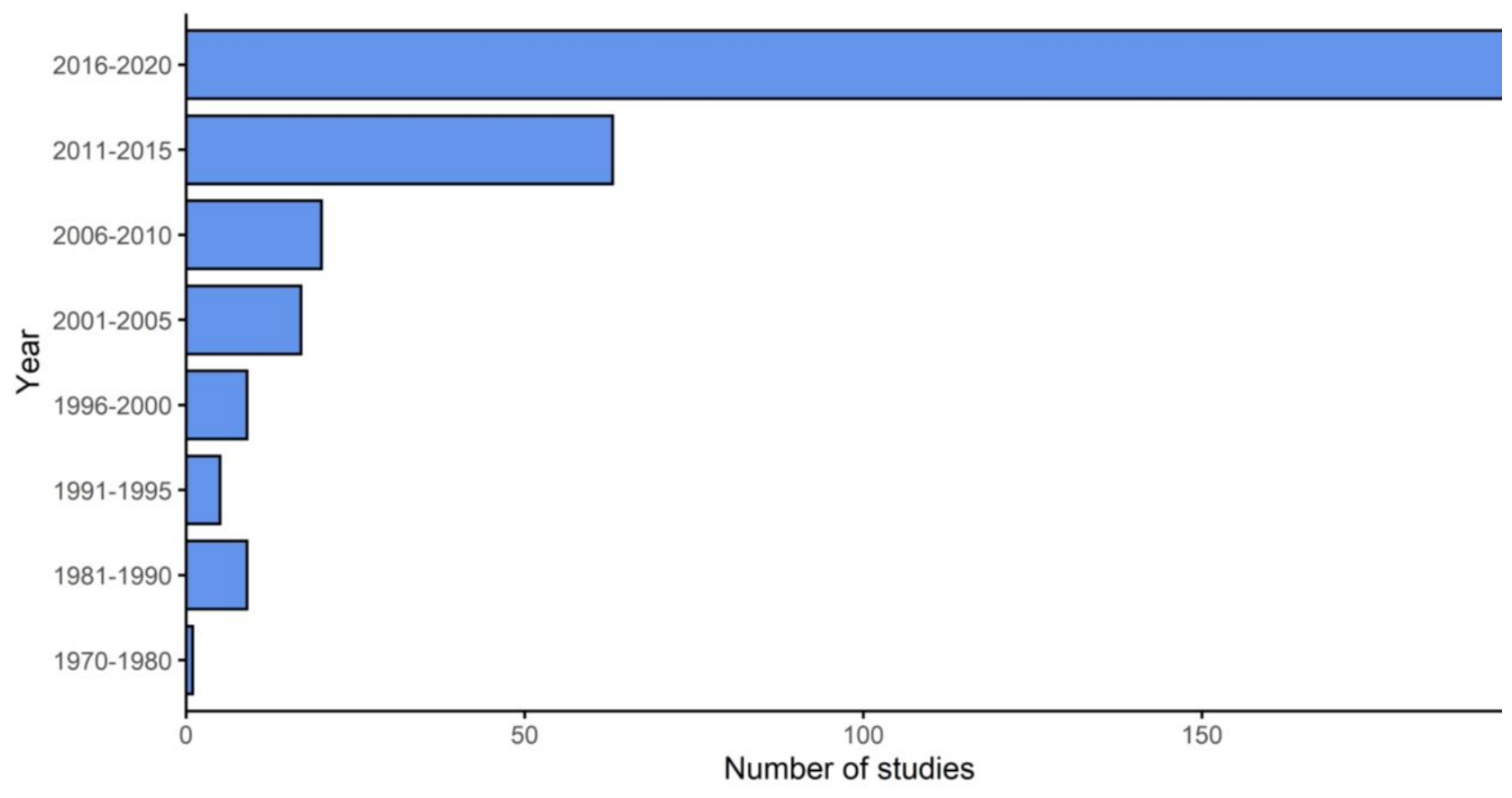

Figure 1. The number of publications reporting plastic ingestion incidence in marine species from estuarine and marine environments. The figure includes 334 studies. Bars indicate the number of published articles. 
plastic ingestion rates of marine species based on the size of the ingested plastics.

\section{Impacts of Plastic Pollution on Marine Biodiversity}

Plastic litter in marine environment is a major threat to global marine diversity. Quantifying the extend of this threat worldwide is quite complex considering different life forms and thousands of species with different ecological requirements. Our oceans now have plastic accumulations magnitude with enormous size covering millions of square kilometers which finally has raised concerns about the potential impact on marine biome. Incidences of plastic exposure on marine species are increasing rapidly. Intentional or unintentional plastic ingestion, snagging and entanglements are causing harm and death. Plastic ingestion was reported from many marine species, from limpets to sperm whales, across globe. Sizes of ingested plastic appeared to be varied depending on size of the animals feeding behavior and habitat.

\section{Uptake of Macroplastics and Mesoplastics}

Aquatic animals can consume macro- and mesoplastics as a food. Studies have shown that more than 250 marine species experience microplastic swallowing or physical exposure (entanglement, snagging, etc.) (Derraik, 2002; Moore, 2008). Sampling location of the studies reporting the plastic ingestion incidences in marine species are presented in Figure 2. Reports revealed that the plastic ingestion cases by a diverse range of marine species even in remote locations (Figure 2) reveals the extent of plastic pollution. Ingestion of plastics is appeared to be not restricted to adult fishes and complex life forms. For instance, microplastic intake was reported from fish larvae (Steer, Cole, Thompson, \& Lindeque, 2017), zooplanktons (Sun et al., 2017), sea stars (Jun Wang, Wang, Ru, \& Liu, 2019), tunicates (Katija, Choy, Sherlock, Sherman, \& Robison, 2017) limpets, sponges, and anemones (Karlsson et al., 2017). In the studies reviewed here, the size of the ingested plastics varied with respect to life forms and species (Figure 3 ).

The size of the detected plastic varies depending on the analytical plastic detection methods as well. The main analytical methods are available to detect plastic from digestive tracts which are; i) visual examination of gut content by naked eye, ii) by microscope and iii) chemical digestion of the gut content, filtration, and microscopic analysis (Markic, Gaertner, GaertnerMazouni, \& Koelmans, 2019). Based on the chosen analytical method sensitivity and detected size of the plastic in a digestive tract may vary. Since the first method, visual examination, is mostly used in large animals such as sea turtles and cetaceans, detected plastics in the digestive tract of the animals are mostly meso, macro, and megaplastics (Figure 3). Due to their small sizes, microplastics are hard to detect with this method which could also explain the low rate detection of microplastic ingestion reports from sea turtles and cetaceans. The third method, chemical digestion of the gut content filtration and microscopic analysis, is the most reliable microplastic detection method. In most of

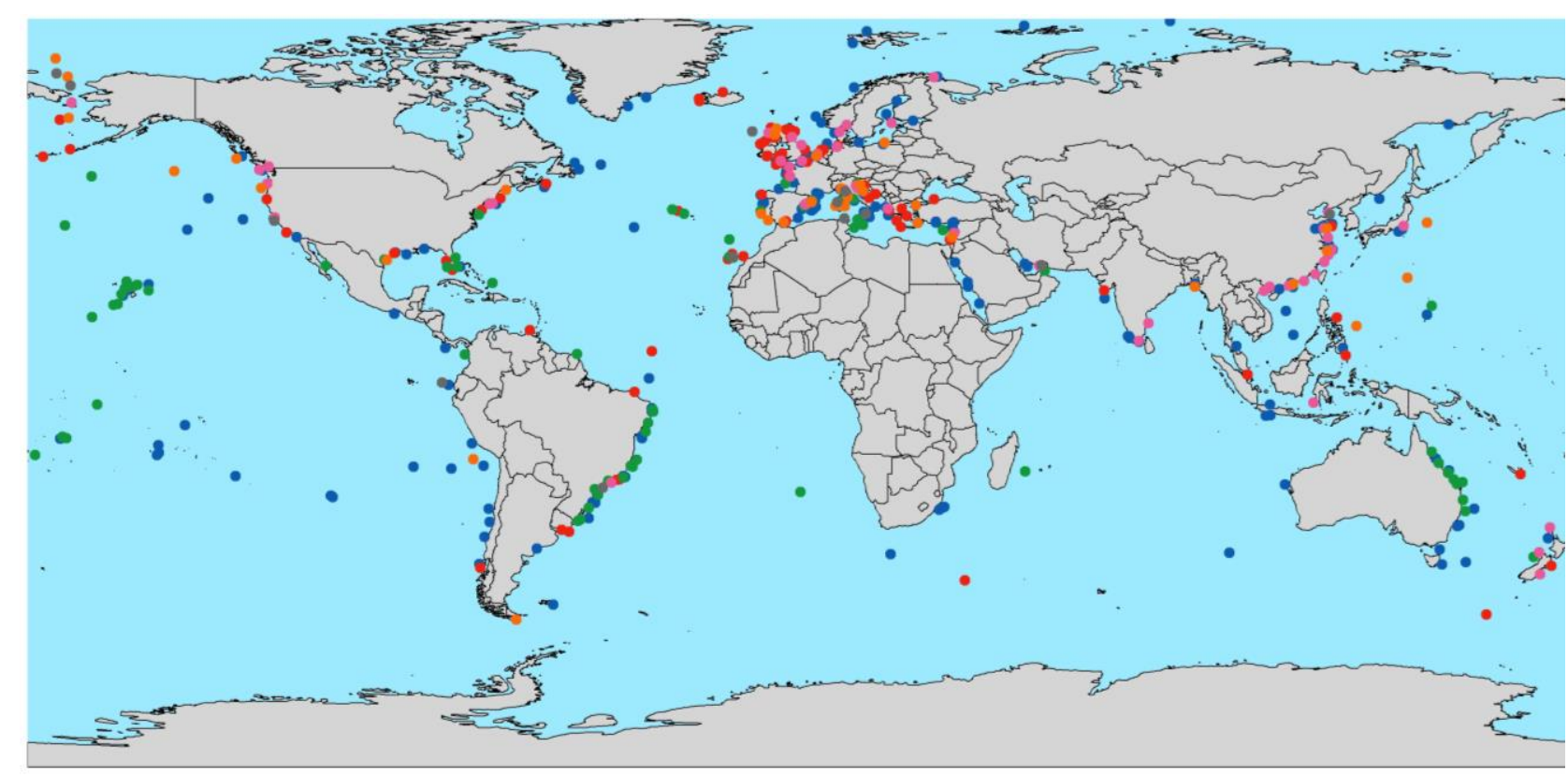

Taxa - Bivalves - Crustaceans - Fish - Mammals - Other Taxa - Sea turtles

Figure 2. Sampling locations of the marine species from which plastic ingestion was reported. Dot colors indicate different groups. Each dot represents a sampling location. 
the recent plastic ingestion studies especially from fish and bivalve species, the third method is used. The second method is a cost-effective method for detecting micro and mesoplastic. However, the sensitivity of this method is way too low than the third method.

While some species ingest plastic directly (primary ingestion) such as planktivorous species, others may ingest plastic indirectly (secondary ingestion) by ingesting prey such as carnivorous species. Secondary ingestion may explain high microplastic accumulation in the digestive tract of predators. Microplastics were mainly found in fish and mollusks, especially in planktivorous species. Larger macro and mesoplastic items were mainly more common in sea turtles and cetaceans (Figure 3). Overall, recorded incidences of megaplastic ingestion were comparatively low and mainly reported from sperm whales which support the hypothesis that plastic resembles prey, particularly squids. Ingestion incidences of meso, macro, and megaplastics by fish were also reported in several papers (Barreto et al., 2019; Choy \& Drazen, 2013; C. Fernández \& Anastasopoulou, 2019; 'Plastics occurrence in the gastrointestinal tract of Zeus faber and Lepidopus caudatus from the Tyrrhenian Sea', n.d.). Sea turtles and cetaceans are among one of the most susceptible species against plastic pollution. Numerous studies were performed on stranded turtles and cetaceans and plastics appeared to be the leading cause of mortality by gastric blockage (Alexiadou, Foskolos, \& Frantzis, 2019; Nelms et al., 2019; Poli, Mesquita, Saska, \& Mascarenhas, 2015). The animals that feed on plastics are also die from starvation because the plastic occupies

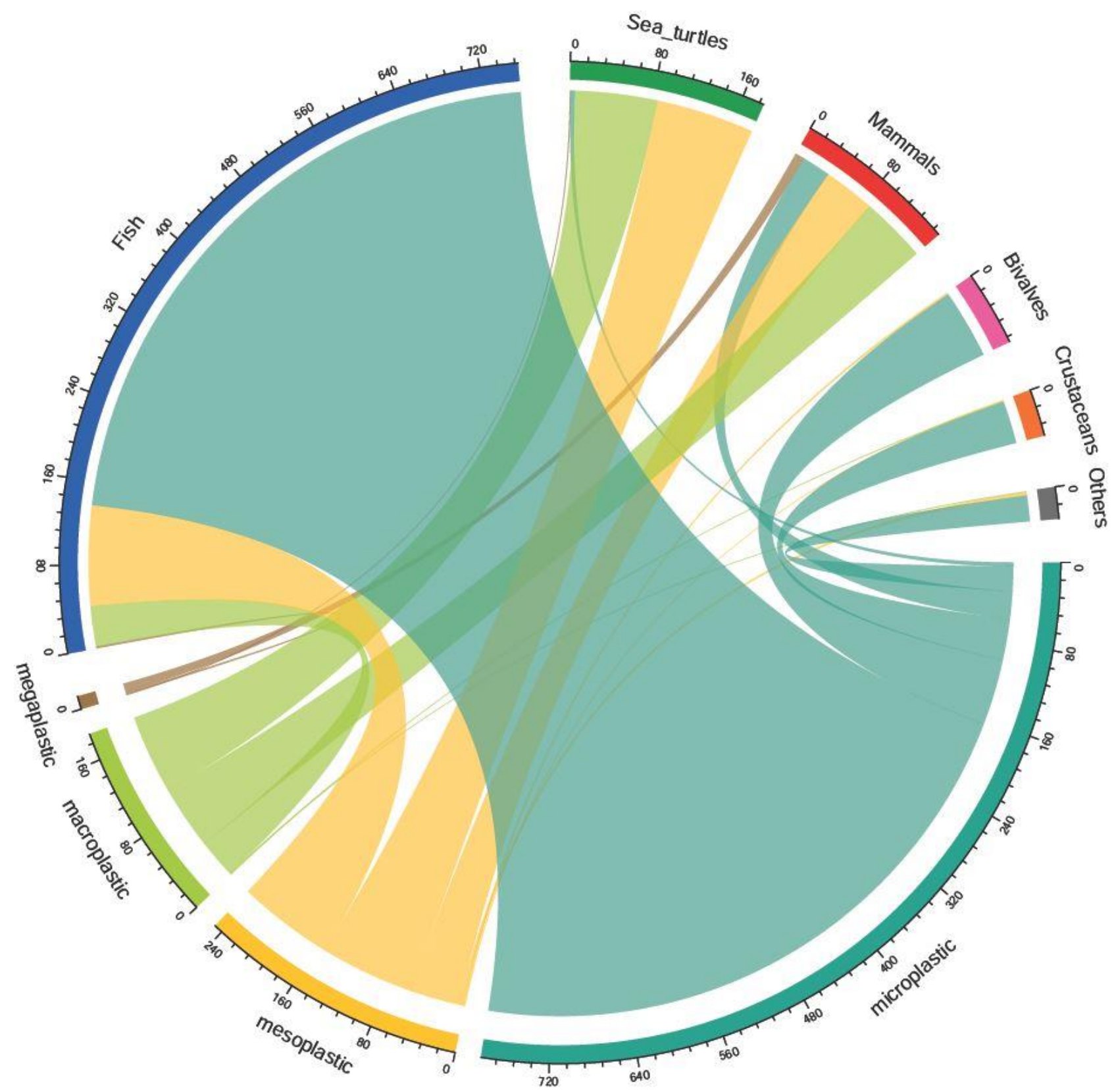

Figure 3. Circlos plot showing the distribution of the plastic ingestion incidences and size of the ingested plastics (Micro, meso, macro and megaplastics) in Fish, Mammals, Sea turtles, Bivalves, Crustaceans and Other taxa. 
space in the stomach and creates a false sense of satiety (Jovanović, 2018), while the animal stomach contains no food. It has been reported that plastics in waters are attached to fish fin and gill, causing physical injury (Rochman et al., 2013; von Moos et al., 2012). Mostly, clean flexible macro and mega size plastic items were found in the stomach of the Sea turtles (Poli et al., 2015; Yaghmour et al., 2018) which resembles jellyfish, their main food source. Accidental but intentional ingestion of plastics that resembles prey, is a clear indication of confusion of plastic with prey (e.g. jelly fish and cephalopods). Preference of translucent color and flexible structure plastics by sea turtles also supports the hypothesis that plastic resembles prey. Similarly, dominance of blue color microplastic in digestive tract of planktivorous species Decapterus muroadsi (Carangidae) (Ory, Sobral, Ferreira, \& Thiel, 2017) also indicates preferential ingestion of prey-like plastics. Despite the exponential rise in published paper related with plastic ingestion of the marine species and negative effects of plastics (Figure 1), studies on the plastic elimination methods are limited.

\section{Microplastics in Marine Systems}

Microplastics are common in all of the oceans. Abundance of the mPS in marine is depending on distance from city center, population of the city, and water currents. Northwestern Pacific Ocean surface water contain 42000 plastic particles $/ \mathrm{km}^{2}$ (Pan, Liu, Sun, Sun, \& Lin, 2019) while the number of plastic particles found in the Arctic waters are low (11.5 plastic particles $/ \mathrm{m}^{3}$ ) (Amy L. Lusher, Tirelli, O'Connor, \& Officer, 2015). mPS concentrations of the Arabian Bay surface waters reach 1.46 million plastic particles $/ \mathrm{km}^{2}$ (Abayomi et al., 2017). Concentrations of mPS observed in urban coastal area of the South Korea are higher than the coastal rural area (Song et al., 2018). Different concentrations of mPS are found in both Greenland (Morgana et al., 2018) and Antarctic Peninsula (Lacerda et al., 2019).

The microplastics abundance in marine sediment is depending on distance from the shoreline, depth of sediment, and flow rate of water. Their concentration in sediment of off-shore is 520-940 particles/kg dw while their concentration increases to $1780-2310$ particles/kg $\mathrm{dw}$ in freshwater - seawater mixing zone. Flow rate of the water is low in mixing zone than in off shore (R. Li, Zhang, Xue, \& Wang, 2019). There is a positive correlation between accumulation of plastic particles and depth of the sediment (Wang et al., 2019).

\section{Uptake of Microplastics and Nanoplastics}

The uptake of microplastics (mPS) or nanoplastics (nPS) by marine species is very common because of their larger specific surface area, smaller size, and bioavailability. While some of the marine species ingest macroplastics and mesoplastics, some of them can only ingest mPS and nPS depending on size of the organism (Xu, Ma, Ji, Pan, \& Miao, 2020).

Abundance, color, density, and shape of the mPS directly affect their bioavailability to marine species. Color of the mPS can be important when marine species select to ingest them because of their resembling to their prey. Some of the fish and their larvae see their prey such as zooplankton and then catch and swallow it. However, some of the zooplankton can resemble yellow, white and tan plastic; thus, fish and their larvae may eat mPS instead of zooplankton (Shaw \& Day, 1994).

\section{Bioaccumulation of mPS}

After ingesting the MPS and nPS by an organism, some of the particles can be eliminated by digesting after some time while some of them are bioaccumulated in different tissue(s) of the marine species. Ingestion of the MPS by marine species is affected by shape and size of the MPS and life stage of the species. Small species such as copepod oyster larvae with early life stage ingest smaller mPS compared to that of larger species. When oyster larval size is increasing or larvae are getting older, size of the consumed mPS increases (Cole \& Galloway, 2015; Cole et al., 2013). Accumulation of fragment shape mPS in grass shrimp is higher than fiber or sphere shape (Gray \& Weinstein, 2017).

Presence of $\mathrm{mPS}$ in aquatic species can be determined/identified with Fourier transformed infrared spectroscopy, optical microscopy, Raman microscopy, scanning electron microscopy, fluorescent spectroscopy and fluorescent microscopy (Ribeiro, O'Brien, Galloway, \& Thomas, 2019). Several studies have shown that the ingestion of MPS by marine species are more common than by freshwater species. Although most of the researches related to presence of $\mathrm{mPS}$ in marine species, information about MPS bioaccumulation mechanism, removal kinetics, toxicity mechanisms and translocation of mPS between tissues or organs is rare.

Aquatic species can get mPS and nPS along with uptake from the water (Guilhermino et al., 2018) and food chain (Cedervall, Hansson, Lard, Frohm, \& Linse, 2012). Although small mPS $(5 \mu \mathrm{m})$ could be accumulated in gut, liver, and gills of zebrafish, when size of the MPS reached to $20 \mu \mathrm{m}$, they could only accumulate in gills and gut of the fish due to the ingestion of the MPS. Accumulated nPS and mPS can cause reproductive problems, pathological stress, enzymes activity problems, oxidative stress, growth reduction disruption in energy cycling, lipid metabolism, liver tissue, and activity of fish (Besseling et al., 2014; Sutton et al., 2016; Chae \& An, 2017; Lu et al., 2016). The microplastics also disrupt lipid bilayer of the cell membrane (Hollóczki \& Gehrke, 2020). Different sizes of the plastic particles can also cause lesions, internal wounds and digestive tract blockage (Jovanović, 2018). Mattsson et al. (Karin Mattsson et al., 2017) demonstrated that the plastic 
nanoparticles of 53 - $180 \mathrm{~nm}$ accumulate in fish brain tissue and cause behavioral disorders.

The microplastics can accumulate in algae and transfer to higher trophic levels such as zooplankton and fish (Cedervall et al., 2012; Chae \& An, 2017). Microplastics are detected from edible tissue of marine species (crustaceans, fish, and mollusks), seafood products (canned sprats and sardines) and sea salt (Toussaint et al., 2019). Therefore, it is very likely that humans can get nPS or MPS through food web.

The nanoplastics compared to MPS have great potential to accumulate in cells or tissue (Lusher et al., 2015). The retention time of the nPS or mPS is important for exchanging chemicals in the tissues or organs of marine animals. Most of the studies related to nPS and mPS are about estimating number, size and type of plastics in intestinal tract of the species (Baalkhuyur et al., 2018; Boerger et al., 2010; Lusher et al., 2013). Although Pitt et al. (Pitt, Trevisan, et al., 2018) claimed that $42 \mathrm{~nm}$ diameter nPS can be transferred vertically from parents to offspring, there is no information available about receiving fluorescent radiation either coming from fluorescently labeled nPS or from the fluorescent molecule detached from the nPS. The nanoplastics smaller than $50 \mathrm{~nm}$ can pass completely through the fish egg chorion and nPS exposure may occur in the embryonic period (Lee et al., 2019).

Micro and nano-sized plastics taken by marine species during the xenobolism process cannot be removed or digested and thus accumulate in the fish (Karin Mattsson et al., 2017; Pitt, Kozal, et al., 2018). In addition to developmental deficiencies in marine species, MPS and nPS cause neurotoxicity, nPS cause DNA damage, cell deaths and oxidative stress (Sökmen et al., 2020), disrupts the immune system (Greven et al., 2016), triggering liver lesions (Lu et al., 2016) and eventually adversely affecting the behavior, physiology and metabolism of the marine species from coral to fish (Brandts et al., 2018; Jeong et al., 2018; Tang et al., 2018; $\mathrm{Yu}$ et al., 2018). Moreover, these nano-sized plastic particles are able to accumulate in body and transfer from one organ to another (Farrell \& Nelson, 2013) and it has been reported that nanoplastics can be transferred from parents to offspring (Pitt, Trevisan, et al., 2018). mPS affect gamete development and fertilization rate of oysters (Sussarellu et al., 2016) and nPS decrease oyster free living stage success by malforming shell (Tallec et al., 2018).

\section{Elimination of mPS from Marine Species}

To eliminate possible effects of $\mathrm{mPS}$, marine species excrete most of the MPS after taking up them to their body. Blue mussel (Mytilus edulis) and Mediterranean mussel (Mytilus galloprovincialis) eliminate $63 \%$ and $70 \%$ of the accumulated $\mathrm{mPS}$ in $6 \mathrm{~h}$ and 24 h, respectively (B. Fernández \& Albentosa, 2019; Woods, Stack, Fields, Shaw, \& Matrai, 2018). After exposing Daphnia magna to mPS, more than $90 \%$ of the
mPS are eliminated in 12 min from the gut (Ogonowski, Schür, Jarsén, \& Gorokhova, 2016).

Elimination rate of the MPS is depending on their size. Gut retention time of the larger particles is less than smaller mPS. Tadpoles depurates $58 \%$ of the $1-\mu \mathrm{m}$ ingested $\mathrm{mPS}$ in $24 \mathrm{~h}$ while $78 \%$ of $10-\mu \mathrm{m} \mathrm{mPS}$ eliminated at the same time period (Hu et al., 2016). After exposing oyster and mussel with 100-nm and 10$\mu \mathrm{m} \mathrm{mPS}$, depuration starts in $6 \mathrm{~h}$ and $24 \mathrm{~h}$, respectively (Ward \& Kach, 2009).

Microplastics can affect aquatic species at the molecular level. mPS cause up-regulation of stressrelated genes in Chinese mitten crab (Eriocheir sinensis) and gilthead seabream (Sparus aurata) (Espinosa, Cuesta, \& Esteban, 2017; P. Yu et al., 2018). Genes related to lipid metabolism signaling pathways, stress response and DNA repair mechanism of Dicentrarchus labrax and Mediterranean mussel have been affected after exposing to mPS (Brandts, Teles, Gonçalves, et al., 2018; Brandts, Teles, Tvarijonaviciute, et al., 2018).

\section{Distribution of mPS in Marine Species}

After ingestion of mPS by marine species, mPS can be accumulated in the digestive tract, gonads, stomach, intestine, viscera, adductor, and mantle tissue (Hu et al., 2016; Kolandhasamy et al., 2018). Digested mPS $(20 \mu \mathrm{m})$ were accumulated in digestive track and hemolymph of clam (Scrobicularia plana) (Ribeiro et al., 2017). HDPE mPS are taken up by mussel (Mytilus edulis) gills and transferred to digestive system. Before accumulating in lysosomal system, mPS move to digestive tubules (von Moos, Burkhardt-Holm, \& Kohler, 2012).

The movement of mPS from one organ or tissue to another is depending on their size. Compare to larger size $\mathrm{mPS}$, small size $\mathrm{mPS}$ easily translocate. Jeong et al. (2018) found that 0.5- 6- $\mu \mathrm{m}$ size mPS limited only in digestive tract of rotifer while $50-\mathrm{nm}$ size mPS scatter in various organs. Distribution of mPS in marine species is influenced by surface charge. Amine polystyrene and carboxyl coated mPS were ingested by the sea urchin. Amine coated mPS were distributed in whole embryos while carboxyl coated mPS were only found in digestive tract (Della Torre et al., 2014).

\section{Effects of Plastics on Photosynthesis}

Up to $80 \%$ of the total oxygen production of the earth coming from oceans and seas. The primary oxygen producer in the marine is phytoplankton (Witman, 2017). Phytoplankton adsorb carbon dioxide from surrounding water and atmosphere and produce oxygen under the sunlight. Therefore, phytoplankton is responsible for reducing greenhouse gas called carbon dioxide. Presence of floating all kinds and all sizes of plastics on the surface of the oceans can interfere with the transmission of the sunlight and consequently reduce the growth of the phytoplankton and thus 
photosynthesis. Toxicity of the plastic particles getting increased with decreasing mPS size. Depending on type of polymer, shape of particle, size of particle, and concentration of the particle, mPS can interact with phytoplankton to form aggregates due to electrostatic attraction between them (Bhattacharya, Lin, Turner, \& $\mathrm{Ke}, 2010)$. These aggregates reduce sunlight absorption and so thus primary production. mPS can also affect reproduction, metabolism, chlorophyll content, photosynthetic activity, and development of the phytoplankton (Mao et al., 2018; Prata, Lavorante, Montenegro, \& Guilhermino, 2018; Sjollema, RedondoHasselerharm, Leslie, Kraak, \& Vethaak, 2016).

\section{Interaction of Microplastics with Other Pollutants}

Microplastics can act as a vector for the bioaccumulation of organic contaminants such as heavy metals, PCBs, PAHs and PBDEs to marine species (Chua, Shimeta, Nugegoda, Morrison, \& Clarke, 2014; Endo et al., 2005). Since mPS have a large surface area, organic contaminants can adhere on the surface of the MPS. Microplastics can also contain different types of additives such as bisphenone, phthalates, bisphenol A, etc. These additives can leak from plastic to water and cause adverse effects to marine species.

Microplastics can soak up polycyclic aromatic hydrocarbons, polychlorinated biphenyls and heavy metals from surrounding water which may exacerbate the contrary effects of nPS on marine species (Koelmans et al., 2016). When these nPS- pollutant complexes are consumed, species can absorb pollutants (Bejgarn, MacLeod, Bogdal, \& Breitholtz, 2015). Thus, nPS contamination is a serious problem in terms of ecotoxicity and environmental risk assessments.

\section{Conclusion}

Everyday plastic items that we use only once and carelessly discard one way or another ends up in the seas and oceans. Marine animals such as fish, mammals, sea birds, sea turtles and many more are bearing the brunt of plastic littering. Reviewed papers and metadata presented in this study provides a glimpse of the effects of plastic pollution in the marine environment. Plastic ingestion incidences recorded in more than 560 species. Yet the number of plastic ingestion records are directly related with the research effort on species. Therefore, it is highly likely that the real number of plastic ingested species are not yet completed, and could be increased by focusing on different species. Moreover, lack of standardized analytical method for detecting plastics in digestive tract is also limiting the detection of size and type of the plastics. Plastics bioaccumulate in different type of tissues and organs of species. While meso- and macroplastics may cause lesions and wounds in digestive tract, micro and nanoplastics accumulate in different tissues. Accumulation of nanoplastics in brain disrupts nervous system and lead behavioral disorders.
Nanoplastics can also be vertically transferred to offspring. The source of these nanoplastics, mostly polystyrene, are daily used plastics including food packages and wraping. Thus these type of disposable plastics should be used more conciously. Instead of littering, plastics should be recycled if applicable. Even better, plastics usage should be restricted and alternative biodegradable, environment friendly material usage should be encouraged.

\section{References}

Abayomi, O. A., Range, P., Al-Ghouti, M. A., Obbard, J. P., Almeer, S. H., \& Ben-Hamadou, R. (2017). Microplastics in coastal environments of the Arabian Gulf. Marine Pollution Bulletin, 124(1), 181-188. https://doi.org/10.1016/j.marpolbul.2017.07.011

Alexiadou, P., Foskolos, I., \& Frantzis, A. (2019). Ingestion of macroplastics by odontocetes of the Greek Seas, Eastern Mediterranean: Often deadly! Marine Pollution Bulletin, $146,67-75$

https://doi.org/10.1016/j.marpolbul.2019.05.055

Allen, V., Kalivas, J. H., \& Rodriguez, R. G. (1999). Postconsumer plastic identification using Raman spectroscopy. Applied Spectroscopy, 53(6), 672-681. https://doi.org/10.1366/0003702991947324

Azevedo-Santos, V. M., Gonçalves, G. R. L., Manoel, P. S., Andrade, M. C., Lima, F. P., \& Pelicice, F. M. (2019). Plastic ingestion by fish: A global assessment. Environmental Pollution, 255, 112994. https://doi.org/10.1016/j.envpol.2019.112994

Baalkhuyur, F. M., Bin Dohaish, E.-J. A., Elhalwagy, M. E. A., Alikunhi, N. M., AlSuwailem, A. M., Røstad, A., ... Duarte, C. M. (2018). Microplastic in the gastrointestinal tract of fishes along the Saudi Arabian Red Sea coast. Marine Pollution Bulletin, 131, 407-415.

https://doi.org/10.1016/j.marpolbul.2018.04.040

Barreto, R., Bornatowski, H., Fiedler, F. N., Pontalti, M., da Costa, K. J., Nascimento, C., \& Kotas, J. E. (2019). Macrodebris ingestion and entanglement by blue sharks (Prionace glauca Linnaeus, 1758) in the temperate South Atlantic Ocean. Marine Pollution Bulletin, 145, 214-218. https://doi.org/10.1016/j.marpolbul.2019.05.025

Bejgarn, S., MacLeod, M., Bogdal, C., \& Breitholtz, M. (2015). Toxicity of leachate from weathering plastics: An exploratory screening study with Nitocra spinipes. Chemosphere, 132, 114-119. https://doi.org/10.1016/j.chemosphere.2015.03.010

Besseling, E., Wang, B., Lürling, M., \& Koelmans, A. A. (2014). Nanoplastic Affects Growth of S. obliquus and Reproduction of D. magna. Environmental Science \& Technology, 48(20), 12336-12343. https://doi.org/10.1021/es503001d

Bhattacharya, P., Lin, S., Turner, J. P., \& Ke, P. C. (2010). Physical adsorption of charged plastic nanoparticles affects algal photosynthesis. Journal of Physical Chemistry C, 114(39), 16556-16561. https://doi.org/10.1021/jp1054759

Boerger, C. M., Lattin, G. L., Moore, S. L., \& Moore, C. J. (2010). Plastic ingestion by planktivorous fishes in the North Pacific Central Gyre. Marine Pollution Bulletin, 60, 22752278. https://doi.org/10.1016/j.marpolbul.2010.08.007

Brandts, I., Teles, M., Gonçalves, A. P., Barreto, A., FrancoMartinez, L., Tvarijonaviciute, A., ... Oliveira, M. (2018). 
Effects of nanoplastics on Mytilus galloprovincialis after individual and combined exposure with carbamazepine. Science of the Total Environment, 643, 775-784. https://doi.org/10.1016/j.scitotenv.2018.06.257

Brandts, I., Teles, M., Tvarijonaviciute, A., Pereira, M. L., Martins, M. A., Tort, L., \& Oliveira, M. (2018). Effects of polymethylmethacrylate nanoplastics on Dicentrarchus labrax. Genomics, 110(6), 435-441.

https://doi.org/10.1016/j.ygeno.2018.10.006

Browne, M. A., Galloway, T., \& Thompson, R. (2007). Microplastic-an emerging contaminant of potential concern? Integrated Environmental Assessment and Management, 3(4), 559-561.

Cedervall, T., Hansson, L. A., Lard, M., Frohm, B., \& Linse, S. (2012). Food chain transport of nanoparticles affects behaviour and fat metabolism in fish. PLOS ONE, 7(2). https://doi.org/10.1371/journal.pone.0032254

Chae, Y., \& An, Y. J. (2017). Effects of micro- and nanoplastics on aquatic ecosystems: Current research trends and perspectives. Marine Pollution Bulletin, 124(2), 624-632. https://doi.org/10.1016/j.marpolbul.2017.01.070

Chatterjee, S., \& Sharma, S. (2019). Microplastics in our oceans and marine health. Field Actions Science Report, 19, 5461.

Choy, A., \& Drazen, J. (2013). Plastic for dinner? Observations of frequent debris ingestion by pelagic predatory fishes from the central North Pacific. Marine Ecology Progress Series, 485, 155-163.

Chua, E. M., Shimeta, J., Nugegoda, D., Morrison, P. D., \& Clarke, B. O. (2014). Assimilation of Polybrominated Diphenyl Ethers from Microplastics by the Marine Amphipod, Allorchestes Compressa. Environmental Science \& Technology, 48(14), 8127-8134.

Cole, M., \& Galloway, T. S. (2015). Ingestion of Nanoplastics and Microplastics by Pacific Oyster Larvae. Environmental Science and Technology, 49(24), 1462514632. https://doi.org/10.1021/acs.est.5b04099

Cole, M., Lindeque, P., Fileman, E., Halsband, C., Goodhead, R., Moger, J., \& Galloway, T. S. (2013). No Title. Environmental Science \& Technology, 47(12), 66466655. https://doi.org/10.1021/es400663f

da Costa, J. P., Santos, P. S. M., Duarte, A. C., \& Rocha-Santos, T. (2016, October). (Nano)plastics in the environment Sources, fates and effects. Science of the Total Environment. Elsevier B.V. https://doi.org/10.1016/j.scitotenv.2016.05.041

Della Torre, C., Bergami, E., Salvati, A., Faleri, C., Cirino, P., Dawson, K. A., \& Corsi, I. (2014). Accumulation and embryotoxicity of polystyrene nanoparticles at early stage of development of sea urchin embryos Paracentrotus lividus. Environmental Science and Technology, 48(20), 12302-12311. https://doi.org/10.1021/es502569w

Derraik, J. G. B. (2002). The pollution of the marine environment by plastic debris: a review. Marine Pollution Bulletin, 44, 842-852.

Ding, J., Zhang, S., Razanajatovo, R. M., Zou, H., \& Zhu, W. (2018). Accumulation, tissue distribution, and biochemical effects of polystyrene microplastics in the freshwater fish red tilapia (Oreochromis niloticus). Environmental Pollution, 238, 1-9. https://doi.org/10.1016/j.envpol.2018.03.001

Endo, S., Takizawa, R., Okuda, K., Takada, H., Chiba, K., Kanehiro, H., ... Date, T. (2005). Concentration of polychlorinated biphenyls (PCBs) in beached resin pellets: Variability among individual particles and regional differences. Marine Pollution Bulletin, 50(10), 1103-1114.

https://doi.org/10.1016/j.marpolbul.2005.04.030

Eriksson, C., \& Burton, H. (2003). Origins and Biological Accumulation of Small Plastic Particles in Fur Seals from Macquarie Island. Ambio, 32(6), 380-384. https://doi.org/10.1579/0044-7447-32.6.380

Erni-Cassola, G., Zadjelovic, V., Gibson, M. I., \& Christie-Oleza, J. A. (2019). Distribution of plastic polymer types in the marine environment; A meta-analysis. Journal of Hazardous Materials, 369(February), 691-698. https://doi.org/10.1016/j.jhazmat.2019.02.067

Espinosa, C., Cuesta, A., \& Esteban, M. Á. (2017). Effects of dietary polyvinylchloride microparticles on general health, immune status and expression of several genes related to stress in gilthead seabream (Sparus aurata L.). Fish and Shellfish Immunology, 68, 251-259. https://doi.org/10.1016/j.fsi.2017.07.006

Fabio, P. (2019). Nanoplastic should be better understood. Nature Nanotechnology, 14, 299-299.

Farrell, P., \& Nelson, K. (2013). Trophic level transfer of microplastic: Mytilus edulis (L.) to Carcinus maenas (L.). Environmental Pollution, 177, 1-3. https://doi.org/10.1016/j.envpol.2013.01.046

Fernández, B., \& Albentosa, M. (2019). Dynamic of small polyethylene microplastics ( $\leq 10 \mathrm{Mm}$ ) in mussel's tissues. Marine Pollution Bulletin, 146, 493-501. https://doi.org/10.1016/j.marpolbul.2019.06.021

Fernández, C., \& Anastasopoulou, A. (2019). Plastic ingestion by blue shark Prionace glauca in the South Pacific Ocean (south of the Peruvian Sea). Marine Pollution Bulletin, 149, 110501.

https://doi.org/10.1016/j.marpolbul.2019.110501

Ferreira, I., Venâncio, C., Lopes, I., \& Oliveira, M. (2019, April). Nanoplastics and marine organisms: What has been studied? Environmental Toxicology and Pharmacology. Elsevier B.V. https://doi.org/10.1016/j.etap.2019.01.006

Gray, A. D., \& Weinstein, J. E. (2017). Size- and shapedependent effects of microplastic particles on adult daggerblade grass shrimp (Palaemonetes pugio). Environmental Toxicology and Chemistry, 36(11), 30743080. https://doi.org/10.1002/etc.3881

Greven, A. C., Merk, T., Karagöz, F., Mohr, K., Klapper, M., Jovanović, B., \& Palić, D. (2016). Polycarbonate and polystyrene nanoplastic particles act as stressors to the innate immune system of fathead minnow (Pimephales promelas). Environmental Toxicology and Chemistry, 35(12), 3093-3100. https://doi.org/10.1002/etc.3501

Guilhermino, L., Vieira, L. R., Ribeiro, D., Tavares, A. S., Cardoso, V., Alves, A., \& Almeida, J. M. (2018). Uptake and effects of the antimicrobial florfenicol, microplastics and their mixtures on freshwater exotic invasive bivalve Corbicula fluminea. Science of the Total Environment, 622-623, 1131-1142. https://doi.org/10.1016/j.scitotenv.2017.12.020

Hollóczki, O., \& Gehrke, S. (2020). Can Nanoplastics Alter Cell Membranes? ChemPhysChem, 21(1), 3-3. https://doi.org/10.1002/cphc.201901156

Horton, A. A. A., Svendsen, C., Williams, R. J. R. J., Spurgeon, D. J. D. J., \& Lahive, E. (2017). Large microplastic particles in sediments of tributaries of the River Thames, UK Abundance, sources and methods for effective quantification. Marine Pollution Bulletin, 114(1), 218- 
226. https://doi.org/10.1016/j.marpolbul.2016.09.004

Hu, L., Su, L., Xue, Y., Mu, J., Zhu, J., Xu, J., \& Shi, H. (2016). Uptake, accumulation and elimination of polystyrene microspheres in tadpoles of Xenopus tropicalis. Chemosphere, 164, 611-617.

https://doi.org/10.1016/j.chemosphere.2016.09.002

Jambeck, J. R., Geyer, R., Wilcox, C., Siegler, T. R., Perryman, M., Andrady, A., \& Law, K. L. (2015). Plastic waste inputs from land into the ocean, 347(6223), 768-771. https://doi.org/10.1126/science.1260352

Jeong, C. B., Kang, H. M., Lee, Y. H., Kim, M. S., Lee, J. S., Seo, J. S., ... Lee, J. S. (2018). Nanoplastic Ingestion Enhances Toxicity of Persistent Organic Pollutants (POPs) in the Monogonont Rotifer Brachionus koreanus via Multixenobiotic Resistance (MXR) Disruption. Environmental Science and Technology, 52(19), 1141111418. https://doi.org/10.1021/acs.est.8b03211

Jovanović, B. (2018). Ingestion of microplastics by fish and its potential consequences from a physical perspective. Integrated Environmental Assessment and Management, 13(3), 510-515.

Karlsson, T. M., Vethaak, A. D., Almroth, B. C., Ariese, F., van Velzen, M., Hassellöv, M., \& Leslie, H. A. (2017). Screening for microplastics in sediment, water, marine invertebrates and fish: Method development and microplastic accumulation. Marine Pollution Bulletin, 122(1-2), 403-408.

https://doi.org/10.1016/j.marpolbul.2017.06.081

Katija, K., Choy, C. A., Sherlock, R. E., Sherman, A. D., \& Robison, B. H. (2017). From the surface to the seafloor: How giant larvaceans transport microplastics into the deep sea. Science Advances, 3, e1700715. https://doi.org/10.1126/sciadv.1700715

Koelmans, A.A., Bakir, A., Burton, G. A., \& Janssen, C. R. (2016). Microplastic as a Vector for Chemicals in the Aquatic Environment: Critical Review and Model-Supported Reinterpretation of Empirical Studies. Environmental Science and Technology, 50(7), 3315-3326. https://doi.org/10.1021/acs.est.5b06069

Koelmans, Albert A., Besseling, E., \& Shim, W. J. (2015). Nanoplastics in the Aquatic Environment. Critical Review. In M. Bergmann, L. Gutow, \& M. Klages (Eds.), Marine Anthropogenic Litter (pp. 325-340). Cham: Springer International Publishing.

Kolandhasamy, P., Su, L., Li, J., Qu, X., Jabeen, K., \& Shi, H. (2018). Adherence of microplastics to soft tissue of mussels: A novel way to uptake microplastics beyond ingestion. Science of the Total Environment, 610-611, 635-640. https://doi.org/10.1016/j.scitotenv.2017.08.053

Lacerda, A. L., Rodrigues, L. S., van Sebille, E., Rodriques, F. L., Ribeiro, L., Secchi, E. R., ... Proietti, M. C. (2019). No Title. Scientific Reports, 9, 3977.

Lechner, A., Keckeis, H., Lumesberger-Loisl, F., Zens, B., Krusch, R., Tritthart, M., ... Schludermann, E. (2014). The Danube so colourful: A potpourri of plastic litter outnumbers fish larvae in Europe's second largest river. Environmental Pollution, 188, 177-181. https://doi.org/10.1016/j.envpol.2014.02.006

Lee, W. S., Cho, H. J., Kim, E., Huh, Y. H., Kim, H. J., Kim, B., ... Jeong, J. (2019). Bioaccumulation of polystyrene nanoplastics and their effect on the toxicity of Au ions in zebrafish embryos. Nanoscale, 11(7), 3200-3207. https://doi.org/10.1039/c8nr09321k

Li, R., Zhang, L., Xue, B., \& Wang, Y. (2019). Abundance and characteristics of microplastics in the mangrove sediment of the semi-enclosed Maowei Sea of the south China sea: New implications for location, rhizosphere, and sediment compositions. Environmental Pollution, 244, 685-692.

https://doi.org/10.1016/j.envpol.2018.10.089

Li, W. C., Tse, H. F., \& Fok, L. (2016). Plastic waste in the marine environment: A review of sources, occurrence and effects. Science of the Total Environment, 566, 333-349.

Lu, Y., Zhang, Y., Deng, Y., Jiang, W., Zhao, Y., Geng, J., ... Ren, H. (2016). Uptake and Accumulation of Polystyrene Microplastics in Zebrafish (Danio rerio) and Toxic Effects in Liver. Environmental Science and Technology, 50(7), 4054-4060. https://doi.org/10.1021/acs.est.6b00183

Lu, Yifeng, Zhang, Y., Deng, Y., Jiang, W., Zhao, Y., Geng, J., ... Ren, H. (2016). Uptake and Accumulation of Polystyrene Microplastics in Zebrafish (Danio rerio) and Toxic Effects in Liver. Environmental Science and Technology, 50(7), 4054-4060. https://doi.org/10.1021/acs.est.6b00183

Lusher, A. L., McHugh, M., \& Thompson, R. C. (2013). Occurrence of microplastics in the gastrointestinal tract of pelagic and demersal fish from the English Channel. Marine Pollution Bulletin, 67, 94-99.

https://doi.org/10.1016/j.marpolbul.2012.11.028

Lusher, Amy L., Tirelli, V., O'Connor, I., \& Officer, R. (2015). Microplastics in Arctic polar waters: the first reported values of particles in surface and sub-surface samples. Scientific Reports, 5, 14947. https://doi.org/10.1038/srep14947

Mao, Y., Ai, H., Chen, Y., Zhang, Z., Zeng, P., Kang, L., ... Li, H. (2018). Phytoplankton response to polystyrene microplastics: Perspective from an entire growth period. Chemosphere, 208, 59-68. https://doi.org/10.1016/j.chemosphere.2018.05.170

Markic, A., Gaertner, J. C., Gaertner-Mazouni, N., \& Koelmans, A. A. (2019). Plastic ingestion by marine fish in the wild. Critical Reviews in Environmental Science and Technology. https://doi.org/10.1080/10643389.2019.1631990

Mattsson, K., Hansson, L. A., \& Cedervall, T. (2015, October). Nano-plastics in the aquatic environment. Environmental Sciences: Processes and Impacts. Royal Society of Chemistry. https://doi.org/10.1039/c5em00227c

Mattsson, Karin, Johnson, E. V., Malmendal, A., Linse, S., Hansson, L. A., \& Cedervall, T. (2017). Brain damage and behavioural disorders in fish induced by plastic nanoparticles delivered through the food chain. Scientific Reports, 7(1), 11452. https://doi.org/10.1038/s41598-017-10813-0

Moore, C. J. (2008). Synthetic polymers in the marine environment: A rapidly increasing, long-term threat. Environmental Research, 108, 131-139.

Morgana, S., Ghigliotti, L., Estévez-Calvar, N., Stifanese, R., Wieckzorek, A., Doyle, T., ... Garaventa, F. (2018). Microplastics in the Arctic: A case study with sub-surface water and fish samples off Northeast Greenland. Environmental Pollution, 242, 1078-1086. https://doi.org/10.1016/j.envpol.2018.08.001

Nelms, S. E., Barnett, J., Brownlow, A., Davison, N. J., Deaville, R., Galloway, T. S., ... Godley, B. J. (2019). Microplastics in marine mammals stranded around the British coast: ubiquitous but transitory? Scientific Reports, 9, 1075. https://doi.org/10.1038/s41598-018-37428-3 
Ogonowski, M., Schür, C., Jarsén, Å., \& Gorokhova, E. (2016). The effects of natural and anthropogenic microparticles on individual fitness in daphnia magna. PLOS ONE, 11(5), 1-20. https://doi.org/10.1371/journal.pone.0155063

Ory, N. C., Sobral, P., Ferreira, J. L., \& Thiel, M. (2017). Amberstripe scad Decapterus muroadsi (Carangidae) fish ingest blue microplastics resembling their copepod prey along the coast of Rapa Nui (Easter Island) in the South Pacific subtropical gyre. Science of the Total Environment, 586, 430-437. https://doi.org/10.1016/j.scitotenv.2017.01.175

Pan, Z., Liu, Q., Sun, Y., Sun, X., \& Lin, H. (2019). Environmental implications of microplastic pollution in the Northwestern Pacific Ocean. Marine Pollution Bulletin, 146, 215-224.

https://doi.org/10.1016/j.marpolbul.2019.06.031

Patel, M. M., Goyal, B. R., Bhadada, S. V., Bhatt, J. S., \& Amin, A. F. (2009). Getting into the brain: approaches to enhance brain drug delivery. CNS Drugs, 23, 35-58. https://doi.org/10.2165/0023210-200923010-00003

Pitt, J. A., Kozal, J. S., Jayasundara, N., Massarsky, A., Trevisan, R., Geitner, N., ... Di Giulio, R. T. (2018). Uptake, tissue distribution, and toxicity of polystyrene nanoparticles in developing zebrafish (Danio rerio). Aquatic Toxicology, 194, 185-194. https://doi.org/10.1016/j.aquatox.2017.11.017

Pitt, J. A., Trevisan, R., Massarsky, A., Kozal, J. S., Levin, E. D., \& Di Giulio, R. T. (2018). Maternal transfer of nanoplastics to offspring in zebrafish (Danio rerio): A case study with nanopolystyrene. Science of the Total Environment, 643, 324-334.

https://doi.org/10.1016/j.scitotenv.2018.06.186

Plastics occurrence in the gastrointestinal tract of Zeus faber and Lepidopus caudatus from the Tyrrhenian Sea. (n.d.).

PlasticsEurope. (2018). Plastics - the facts 2018.

Poli, C., Mesquita, D. O., Saska, C., \& Mascarenhas, R. (2015). Ingestão de plástico por tartarugas marinhas no estado da Paraíba, Nordeste do Brasil. Iheringia - Serie Zoologia, 105(3), 265-270. https://doi.org/10.1590/1678476620151053265270

Prata, J. C., Lavorante, B. R. B. O., B.S.M. Montenegro, M. D. C., \& Guilhermino, L. (2018). Influence of microplastics on the toxicity of the pharmaceuticals procainamide and doxycycline on the marine microalgae Tetraselmis chuii. Aquatic Toxicology, 197, 143-152. https://doi.org/10.1016/j.aquatox.2018.02.015

Ren, X.-W., Tang, J.-C., Yu, C., \& He, J. (2018). Advances in research on the ecological effects of microplastic pollution on soil ecosystems. Journal of AgroEnvironment Science, 37(6), 1045-1058. https://doi.org/10.11654/jaes.2017-1409

Retama, I., Jonathan, M. P., Shruti, V. C., Velumani, S., Sarkar, S. K., Roy, P. D., \& Rodríguez-Espinosa, P. F. (2016). Microplastics in tourist beaches of Huatulco Bay, Pacific coast of southern Mexico. Marine Pollution Bulletin, 113(1-2), 530-535. https://doi.org/10.1016/j.marpolbul.2016.08.053

Ribeiro, F., Garcia, A. R., Pereira, B. P., Fonseca, M., Mestre, N. C., Fonseca, T. G., ... Bebianno, M. J. (2017). Microplastics effects in Scrobicularia plana. Marine Pollution Bulletin, 122(1-2), 379-391. https://doi.org/10.1016/j.marpolbul.2017.06.078

Ribeiro, F., O'Brien, J. W., Galloway, T., \& Thomas, K. V. (2019). Accumulation and fate of nano- and micro-plastics and associated contaminants in organisms. TrAC - Trends in
Analytical Chemistry, 111, 139-147.

https://doi.org/10.1016/j.trac.2018.12.010

Schwarz, A. E., Ligthart, T. N., Boukris, E., \& van Harmelen, T. (2019). Sources, transport, and accumulation of different types of plastic litter in aquatic environments: A review study. Marine Pollution Bulletin, 143, 92-100. https://doi.org/10.1016/j.marpolbul.2019.04.029

Shaw, D. G., \& Day, R. H. (1994). Colour- and form- dependent loss of plastic micro-debris from the North Pacific Ocean. Marine Pollution Bulletin, 28(1), 39-43.

Šilc, U., Küzmič, F., Caković, D., \& Stešević, D. (2018). Beach litter along various sand dune habitats in the southern Adriatic (E Mediterranean). Marine Pollution Bulletin, 128, 353-360.

Sjollema, S. B., Redondo-Hasselerharm, P., Leslie, H. A., Kraak, M. H. S., \& Vethaak, A. D. (2016). Do plastic particles affect microalgal photosynthesis and growth? Aquatic Toxicology, 170, 259-261. https://doi.org/10.1016/j.aquatox.2015.12.002

Sökmen, T. Ö., Sulukan, E., Türkoğlu, M., Baran, A., Özkaraca, M., \& Ceyhun, S. B. (2020). Polystyrene nanoplastics (20 $\mathrm{nm}$ ) are able to bioaccumulate and cause oxidative DNA damages in the brain tissue of zebrafish embryo (Danio rerio). NeuroToxicology, 77, 51-59. https://doi.org/10.1016/j.neuro.2019.12.010

Song, Y. K., Hong, S. H., Eo, S., Jang, M., Han, G. M., Isobe, A., \& Shim, W. J. (2018). Horizontal and Vertical Distribution of Microplastics in Korean Coastal Waters. Environmental Science and Technology, 52(21), 1218812197. https://doi.org/10.1021/acs.est.8b04032

Steer, M., Cole, M., Thompson, R. C., \& Lindeque, P. K. (2017). Microplastic ingestion in fish larvae in the western English Channel. Environmental Pollution, 226, 250-259. https://doi.org/10.1016/j.envpol.2017.03.062

Stephens, B., Azimi, P., El Orch, Z., \& Ramos, T. (2013). Ultrafine particle emissions from desktop 3D printers. Atmospheric Environment, 79, 334-339. https://doi.org/10.1016/j.atmosenv.2013.06.050

Sun, X., Li, Q., Zhu, M., Liang, J., Zheng, S., \& Zhao, Y. (2017). Ingestion of microplastics by natural zooplankton groups in the northern South China Sea. Marine Pollution Bulletin, 115(1-2), 217-224. https://doi.org/10.1016/j.marpolbul.2016.12.004

Sussarellu, R., Suquet, M., Thomas, Y., Lambert, C., Fabioux, C., Pernet, M. E. J., ... Philippe Huvet, A. (2016). Oyster reproduction is affected by exposure to polystyrene microplastic. Proceedings of the National Academy of Sciences of the United States of America, 113(9), 24302435.

Sutton, R., Mason, S. A. S. A., Stanek, S. K. S. K., Willis-Norton, E., Wren, I. F. I. F., \& Box, C. (2016). Microplastic contamination in the San Francisco Bay, California, USA. Marine Pollution Bulletin, 109(1), 230-235. https://doi.org/10.1016/j.marpolbul.2016.05.077

Tallec, K., Huvet, A., Di Poi, C., González-Fernández, C., Lambert, C., Petton, B., ... Paul-Pont, I. (2018). Nanoplastics impaired oyster free living stages, gametes and embryos. Environmental Pollution, 242, 1226-1235. https://doi.org/10.1016/j.envpol.2018.08.020

Tang, J., Ni, X., Zhou, Z., Wang, L., \& Lin, S. (2018). Acute microplastic exposure raises stress response and suppresses detoxification and immune capacities in the scleractinian coral Pocillopora damicornis. Environmental Pollution, 243, 66-74. https://doi.org/10.1016/j.envpol.2018.08.045 
Toussaint, B., Raffael, B., Angers-Loustau, A., Gilliland, D., Kestens, V., Petrillo, M., ... Van den Eede, G. (2019, May). Review of micro- and nanoplastic contamination in the food chain. Food Additives and Contaminants - Part A Chemistry, Analysis, Control, Exposure and Risk Assessment. Taylor and Francis Ltd. https://doi.org/10.1080/19440049.2019.1583381

von Moos, N., Burkhardt-Holm, P., \& Kohler, A. (2012). Uptake and effects of microplastics on cells and tissue of the blue mussel Mytilus edulis L. after an experimental exposure. Environmental Science \& Technology, 46(20), 11327-11335.

Wang, J., Wang, M., Ru, S., \& Liu, X. (2019). High levels of microplastic pollution in the sediments and benthic organisms of the South Yellow Sea, China. Science of the Total Environment, 651, 1661-1669. https://doi.org/10.1016/j.scitotenv.2018.10.007

Wang, Jun, Wang, M., Ru, S., \& Liu, X. (2019). High levels of microplastic pollution in the sediments and benthic organisms of the South Yellow Sea, China. Science of the Total Environment, 651, 1661-1669.

https://doi.org/10.1016/j.scitotenv.2018.10.007

Wang, W., Ge, J., \& Yu, X. (2020). Bioavailability and toxicity of microplastics to fish species: A review. Ecotoxicology and Environmental Safety, 189, 109913. https://doi.org/10.1016/j.ecoenv.2019.109913

Ward, J. E., \& Kach, D. J. (2009). Marine aggregates facilitate ingestion of nanoparticles by suspension-feeding bivalves. Marine Environmental Research, 68(3), 137142. https://doi.org/10.1016/j.marenvres.2009.05.002

Witman, S. (2017). World's biggest oxygen producers living in swirling ocean waters. Earth \& Space Science News, 98. https://doi.org/https://doi.org/10.1029/2017EO081067

Woods, M. N., Stack, M. E., Fields, D. M., Shaw, S. D., \& Matrai, P. A. (2018). Microplastic fiber uptake, ingestion, and egestion rates in the blue mussel (Mytilus edulis).
Marine Pollution Bulletin, 137, 638-645. https://doi.org/10.1016/j.marpolbul.2018.10.061

World Economic Forum. (2016). The New Plastics EconomyRethinking the future of plastics.

Wu, C., Nahil, M. A., Miskolczi, N., Huang, J., \& Williams, P. T. (2016). Production and application of carbon nanotubes, as a co-product of hydrogen from the pyrolysis-catalytic reforming of waste plastic. Process Safety and Environmental Protection, 103, 107-114. https://doi.org/10.1016/j.psep.2016.07.001

Xu, S., Ma, J., Ji, R., Pan, K., \& Miao, A. J. (2020). Microplastics in aquatic environments: Occurrence, accumulation, and biological effects. Science of the Total Environment, 703. https://doi.org/10.1016/j.scitotenv.2019.134699

Yaghmour, F., Al Bousi, M., Whittington-Jones, B., Pereira, J., Garcia-Nunez, S., \& Budd, J. (2018). Marine debris ingestion of green sea turtles, Chelonia mydas, (Linnaeus, 1758) from the eastern coast of the United Arab Emirates. Marine Pollution Bulletin2, 135, 55-61.

Yu, P., Liu, Z., Wu, D., Chen, M., Lv, W., \& Zhao, Y. (2018). Accumulation of polystyrene microplastics in juvenile Eriocheir sinensis and oxidative stress effects in the liver. Aquatic Toxicology, 200(April), 28-36. https://doi.org/10.1016/j.aquatox.2018.04.015

Yu, Y., Zhou, D., Li, Z., \& Zhu, C. (2018). Advancement and Challenges of Microplastic Pollution in the Aquatic Environment: a Review. Water, Air, and Soil Pollution, 229(5). https://doi.org/10.1007/s11270-018-3788-z

Zhang, H., Kuo, Y.-Y., Gerecke, A. C., \& Wang, J. (2012). CoRelease of Hexabromocyclododecane (HBCD) and Nanoand Microparticles from Thermal Cutting of Polystyrene Foams. Environmental Science \& Technology, 46(20), 10990-10996. https://doi.org/10.1021/es302559

Zitko, V., \& Hanlon, M. (1991). Another source of pollution by plastics: skin cleaners with plastic scrubbers. Marine Pollution Bulletin, 22, 41-42. 